\title{
Management Rice Livestock Integration System Based Local Institutional (Descriptive Study of "Mawar" Farmers Group in Lubuk Bayas village, Sub District of Perbaungan, Regency of Serdang Bedagai, Province of Sumatera Utara).
}

Fajar Utama Ritonga, Husni Thamrin

Social Welfare Department, Faculty of Social's Saince and Political Saince, University of Sumatera Utara Medan, Indonesia

\begin{abstract}
Mawar" Farmers Group are Local Intitutional in managing Rice Livestock Integration System, in Lubuk Bayas village, Sub District Perbaungan, Regency of Serdang Bedagai, Province of Sumatera Utara. The purpose of this research is describing management program Rice Livestock Integration System, and to analysis the factors reinforcing local institutional. This study used a qualitative approach with descriptive research. Selection of informants was done by using purposive sampling and snowball sampling.The results of research showed three pillars management programa managing Rice Livestock Integration System, namely: (1) regulative pillar, (2) normative pillars, (3) cognitive cultural pillar. And factors reinforcing local institutional as follows : (1) economic factors, (2) social and culture factors, (3) knowledge factors, (4) the pride factors, (5) venture capital assistance factors.
\end{abstract}

Keywords: Food Security, Local Institutional, Rice Livestock Integration System (SIPT), Farmers

\section{INTRODUCTION}

Today, the world is overshadowed by the food crisis in the coming years, with respect to population growth and unfair growth in food production. The imbalance is due to the demand for food that exceeds its production. The situation can be seen from the forecast of the world food balance in 2025 as follows:

Table 1.1 World Food Balance Estimation Year 2025

\begin{tabular}{|c|c|c|c|c|c|}
\hline Region & $\begin{array}{c}\text { Popu } \\
\text { latio } \\
n \\
2025 \\
\end{array}$ & $\begin{array}{l}\text { Consu } \\
\text { mtion/ } \\
\text { Capita }\end{array}$ & $\begin{array}{c}\text { Dema } \\
\text { nd } \\
2025\end{array}$ & $\begin{array}{c}\text { Prod } \\
\text { uctio } \\
n \\
2025\end{array}$ & $\begin{array}{c}\text { Balan } \\
\text { cing } \\
2025\end{array}$ \\
\hline $\begin{array}{l}\text { South } \\
\text { Asia }\end{array}$ & $\begin{array}{c}2,02 \\
1 \\
\end{array}$ & 237 & $5,89.7$ & $\begin{array}{c}524 . \\
6 \\
\end{array}$ & -25.1 \\
\hline $\begin{array}{l}\text { East } \\
\text { and } \\
\text { Southea } \\
\text { st Asia } \\
\end{array}$ & $\begin{array}{c}2,38 \\
7\end{array}$ & 338 & $\begin{array}{c}1,040 . \\
9\end{array}$ & $\begin{array}{c}914 . \\
0\end{array}$ & $\begin{array}{c}- \\
126.9\end{array}$ \\
\hline $\begin{array}{l}\text { Latin } \\
\text { America }\end{array}$ & 690 & 265 & 217.9 & $\begin{array}{c}171 . \\
2 \\
\end{array}$ & -46.7 \\
\hline $\begin{array}{l}\text { North } \\
\text { America }\end{array}$ & 410 & 780 & 319.5 & $\begin{array}{c}558 . \\
2 \\
\end{array}$ & 238.7 \\
\hline World & $\begin{array}{c}8,03 \\
9 \\
\end{array}$ & 363 & $\begin{array}{c}3,046 . \\
5\end{array}$ & $\begin{array}{c}2,97 \\
7.7 \\
\end{array}$ & -68.8 \\
\hline
\end{tabular}

Source: Wafa, 2013

Based on the above table for Indonesia, it is estimated that by 2025 the population will reach
273 million people, who need staple food-rice of 38 million tons or equivalent to 72 million tons of grain.

aware of the food crisis Serdang Bedagai regency as one of the contributors of rice selfsufficiency in North Sumatera Province has implemented Livestock Integration System using local institution farmer group as the driving force.

This study focuses on highlighting the locality of a community of "Mawar" farmer group in manages program livestock integration system. Which is "Mawar" Farmers Group use the norms, rules and understanding of farmer groups according to their local wisdom.

At first this program was implemented in a top-bottom manner without involving participation, local wisdom and local institutions of the Mawar Farmer Group, resulting in many problems such as no sense of ownership, no responsibility for work, lack of awareness of farmer groups. This has an impact on the first year of program Livestock Integration System is not running maximally.

After evaluating by Badan Penyuluh Pertanian Ketahanan Pangan (BP2KP) as the facilitator of the program, noted that local institutional role in the management program livestock integration system is need. Then in the second phase the program livestock integration system increased the participation of farmer group members. These results have an impact improve 
obtained in accordance with program objectives of producing manure for organic farming and cattle raising for breeding and taken benefits such as meat and milk and can be sold. (Sembiring, 2002)

Table 2. Differences in SIPT Processing in Lubuk Bayas Village

\begin{tabular}{|c|c|c|c|}
\hline \multicolumn{2}{|c|}{ Model 1} & \multicolumn{2}{|c|}{ Model 2} \\
\hline Parameter & $\begin{array}{l}\text { Lubuk } \\
\text { Bayas } \\
\text { Village }\end{array}$ & $\begin{array}{c}\text { Paramet } \\
\text { er }\end{array}$ & $\begin{array}{c}\text { Desa Lubuk } \\
\text { Bayas }\end{array}$ \\
\hline $\begin{array}{l}\text { Type of } \\
\text { business }\end{array}$ & $\begin{array}{l}\text { Cattle } \\
\text { breedin } \\
\text { g }\end{array}$ & $\begin{array}{l}\text { Type of } \\
\text { business }\end{array}$ & $\begin{array}{l}\text { Breeding of } \\
\text { cattle since } \\
2003\end{array}$ \\
\hline $\begin{array}{l}\text { Number } \\
\text { of Cows }\end{array}$ & $\begin{array}{l}80 \\
\text { heads } \\
\text { for } 80 \\
\text { farmers }\end{array}$ & $\begin{array}{l}\text { Number } \\
\text { of Cows }\end{array}$ & $\begin{array}{lr}72 \text { head of } \\
\text { parent } & 2 \\
\text { male tail } & \end{array}$ \\
\hline $\begin{array}{l}\text { Type of } \\
\text { Cows }\end{array}$ & $\begin{array}{l}\text { Madras, } \\
\text { Brahma } \\
\text { n, } \\
\text { Simenta } \\
\text { l. }\end{array}$ & $\begin{array}{l}\text { Type of } \\
\text { Cows }\end{array}$ & $\begin{array}{l}\text { Madras, } \\
\text { Brahman, } \\
\text { Simental, }\end{array}$ \\
\hline $\begin{array}{l}\text { Type of } \\
\text { Cage }\end{array}$ & $\begin{array}{l}\text { Group } \\
\text { enclosu } \\
\text { re (4 } \\
\text { unit), } \\
\text { land } \\
\text { lease } \\
\text { system. }\end{array}$ & $\begin{array}{l}\text { Type of } \\
\text { Cage }\end{array}$ & $\begin{array}{l}\text { Group and } \\
\text { Individuality }\end{array}$ \\
\hline Feeding & $\begin{array}{l}\text { Straw, } \\
\text { Fereme } \\
\text { ntation, } \\
\text { Grass } \\
\text { and } \\
\text { Agricult } \\
\text { ural } \\
\text { remain } \\
\end{array}$ & $\begin{array}{l}\text { Marriag } \\
\text { e System }\end{array}$ & $\begin{array}{l}\text { Artificial } \\
\text { Insemination, } \\
\text { Natural } \\
\text { Mating }\end{array}$ \\
\hline $\begin{array}{l}\text { Marriage } \\
\text { System }\end{array}$ & $\begin{array}{l}\text { Artificia } \\
\text { l } \\
\text { Insemin } \\
\text { ation, } \\
\text { Natural } \\
\text { Mating } \\
\end{array}$ & Calves & $\begin{array}{lr}25 & \text { Calve } \\
\text { (dead } 5 \text { ekor) }\end{array}$ \\
\hline $\mathrm{CA}$ & $\begin{array}{l}\text { Revenu } \\
\text { e Share } \\
\text { by } \\
\text { "KUAT" }\end{array}$ & Sales & $\begin{array}{l}20 \text { tail (worth } \\
\text { Rp. } 40.000 .00 \\
\text { 0) Individual } \\
\text { benefits with } \\
\text { joint } \\
\text { management }\end{array}$ \\
\hline
\end{tabular}

Sumber: Khairia, 2007.

The table above is a comparison of service model of program Livestock Management System in Lubuk Bayas Village conducted by Facilitator of Badan Penyuluh Pertanian Ketahanan Pangan
(BP2KP) District of Serdang Bedagai. The first model implemented, excluding the local institution "Kelompok Tani Mawar" as the owner or program manager of the result is the low participation of group members in managing program livestock management sytem in the group cage, and also due to unclear division of return or profit with the profit sharing system under one management together.

The weakness of this first model if there is a member who is absent the management of cleaning the cage, searching and feeding is the responsibility of a particular person only and this resulted in the burden for diligent members, there are also certain members who are lazy to work that makes a variety of reasons that do not make sense, finally some have withdrawn and cows are less well groomed.

The second model involves local institutional elements. The Livestock Management System program is run on the local understanding of the "Mawar" Farmer Group by combining information and technology knowledge from (BP2KP) District Serdang Bedagai. This increases the participation of members of the "Mawar" Farmer Group in working to manage the livestock management system program and make the farmers have a high sense of belonging to the Livestock Management System program.

The role of local institutions becomes very important in increasing community participation so that bottom-up and people centered community empowerment can be achieved. Therefore, this study will examine:

1. How is the Management of Integrated Animal Farming System run by the "Mawar" farmer group in Lubuk Bayas Village Perbaungan District Serdang Bedagai Regency of North Sumatra Province?

2. Factors that strengthen the local institutional presence of "Mawar" Farmer Group still survive until now?

\section{THEORETICAL REVIEW}

\section{A.Food Security}

Food security based on Law No. 7/1996 on food security is defined as a condition of the fulfillment of food at the household level as reflected by the availability of good quality food, safe, equitable, and affordable. While the limits used by The World Food Summit (1996) at the 
time of triggering FIVIMS (Food Insecurity and Vulnerability Information and Mapping Systems) are food security is a condition where everyone, at all times, has physical, social, and economic access to food which is safe and nutritious so it is enough to meet the needs of the body in accordance with his beliefs so as to live an active and healthy life. (Sastraatmadja, 2006).

According to the Law of the Republic of Indonesia Number 18 Year 2012, regarding food, it is explained that food is anything that comes from biological sources of agricultural, plantation, forestry, fishery, livestock, aquatic, and water production both processed and processed as food and beverages for human consumption including food additives, foodstuffs and other materials used in the process of preparing, processing and / or making food or drink.

Based on the definition of food security in Law No. RI. 7 of 1996 which adopted FAO (Food Association Organization) and Law number: 18 of 2012 on food, got 5 components that must be fulfilled to achieve the condition of food resilience that is:

1. Adequacy of food availability.

2. Stability of food availability.

3. Fluctuations from season to season or from year to year.

4. Accessibility/affordability to food as well as.

5. Quality/food safety. (Maleha, 2006)

\section{B.Farmers Welfare}

Farmer exchange rate is defined as a measure of the ability of agricultural goods (product) produced by farmers on goods and services needed for household consumption and the need to produce agricultural products. Farmers Exchange Rate is obtained from the percentage of price index ratio received by farmer (It) with price index paid by farmer (Ib). It includes food crops and smallholder plantation crops, while (Ib) includes household consumption and production costs and additional capital goods (Ministry of Agriculture, 2003), in (Muchjidin 2013, p.114)

\section{C.Concept of Local Indtitution}

Table 3. The concept of local institutions from three perspectives

\begin{tabular}{|c|c|c|}
\hline $\begin{array}{l}\text { Perspective Rational } \\
\text { Choice Theory }\end{array}$ & $\begin{array}{l}\text { Perspective } \\
\text { Sosiologi- } \\
\text { Antropologi }\end{array}$ & $\begin{array}{l}\text { Perspective } \\
\text { Sosiologi } \\
\text { Pengetahuan }\end{array}$ \\
\hline $\begin{array}{l}\text { Hendropuspito } \\
\text { (Wibowo,2011,h.57) "A } \\
\text { form of organization } \\
\text { that is constantly } \\
\text { composed of patterns } \\
\text { of behavior, roles and } \\
\text { relationships as a } \\
\text { means of binding in } \\
\text { order to achieve basic } \\
\text { social needs "” }\end{array}$ & $\begin{array}{l}\text { Durkheim } \\
\text { (Scoot,2008,h.12) } \\
\text { "Social institution is } \\
\text { symbolic systems- } \\
\text { systems of } \\
\text { knowledge, belief, } \\
\text { and moral } \\
\text { authority from } \\
\text { product of joint } \\
\text { activity and } \\
\text { association". }\end{array}$ & $\begin{array}{l}\text { Berger anf } \\
\text { Luckmann } \\
\text { (Scoot,2008,h.16) } \\
\text { 'Institution is } \\
\text { product of social } \\
\text { interaction } \\
\text { emphasized the } \\
\text { creation of shared } \\
\text { knowledge and } \\
\text { belief system rather } \\
\text { than the production } \\
\text { of rule and norm" }\end{array}$ \\
\hline $\begin{array}{l}\text { Sabaruddin } \\
\text { (Wibowo,2011,h,55.) } \\
\text { "A set of real } \\
\text { relationships of norms, } \\
\text { beliefs and values } \\
\text { centered on social } \\
\text { needs and a series of } \\
\text { important and } \\
\text { repetitive actions". }\end{array}$ & $\begin{array}{l}\text { Uphoff (1986,h.9) } \\
\text { "Social institution is } \\
\text { complexes of norm } \\
\text { and behavior that } \\
\text { persist over time } \\
\text { serving collectivity } \\
\text { valued purposes" }\end{array}$ & $\begin{array}{l}\text { Smith (2005,h.29) } \\
\text { "Reorganized the } \\
\text { social relation of } \\
\text { knowledge of social } \\
\text { so people can take } \\
\text { that knowledge up } \\
\text { as an extension of } \\
\text { our ordinary } \\
\text { knowledge of local } \\
\text { actualieis of our life" }\end{array}$ \\
\hline $\begin{array}{l}\text { Taneko (Wibowo, } \\
\text { 2011.h.55) } \\
\text { "Institutionality as the } \\
\text { existence of norms and } \\
\text { needs of society in the } \\
\text { situation" }\end{array}$ & $\begin{array}{l}\text { Parsons } \\
\text { (Scoot,1995,h.12) } \\
\text { "Institution is a } \\
\text { system of norms } \\
\text { that regulate the } \\
\text { relations of } \\
\text { individuals to each } \\
\text { other and that } \\
\text { define "what the } \\
\text { rlation of }\end{array}$ & $\begin{array}{l}\text { Zucker } \\
\text { (Scoot,2008,h.43) } \\
\text { "Stressed the power } \\
\text { of cognitive belief to } \\
\text { anchor behavior, } \\
\text { social knowledge, } \\
\text { once } \\
\text { institutionalized } \\
\text { exixts as fact, as part } \\
\text { of objective reality }\end{array}$ \\
\hline $\begin{array}{l}\text { Point: Institutions to } \\
\text { regulate behavior and } \\
\text { fulfillment of human } \\
\text { needs so that human } \\
\text { beings seek to } \\
\text { maximize profit by } \\
\text { using rules }\end{array}$ & $\begin{array}{l}\text { Point: Institution } \\
\text { emerges as the } \\
\text { existence of human } \\
\text { behavior either } \\
\text { individually or as a } \\
\text { group determined } \\
\text { by the norms living } \\
\text { in the community } \\
\text { concerned, so that } \\
\text { humans are actors } \\
\text { who obey the norm }\end{array}$ & $\begin{array}{l}\text { Point: Institutional } \\
\text { outcomes of the } \\
\text { process of culture } \\
\text { and knowledge } \\
\text { (cognitive), so that } \\
\text { human all things } \\
\text { around including } \\
\text { norms and } \\
\text { regulations. Humans } \\
\text { do not directly } \\
\text { obedient completely } \\
\text { because of } \\
\text { interpreting the } \\
\text { norms and rules } \\
\text { that exist, then } \\
\text { choose their own } \\
\text { attitudes and } \\
\text { regulations because } \\
\text { humans are active } \\
\text { actors. }\end{array}$ \\
\hline
\end{tabular}

Source: Reprocessed by the researcher

Based on the definition of the above figures, it can be concluded that the institutional presence in the community because the condition of society is met by various rules and behaviors by 
looking at these rules as norms or rules that apply and binding within and among the community. To regulate human behavior, institutional as a media or container in forming patterns that have a fixed power and activities to meet the needs must be run through the patterns that exist in the institutional. Man will endeavor to maximize his own advantage by using or dodging the rules that have been in form through the institutional. Through institutions that are created to regulate patterns of behavior and the fulfillment of human needs, the institutional existence will contribute (profit) to the life of the community.

\section{F. New Institutional Theory}

Scoot (2008, p.50) argues that the new institutional presence emphasizes service to (1) control community capacity and limit behavior; (2) provides restrictions with legal, moral and cultural boundaries; (3) departing from the lawful from unlawful activity; (4) supporting and encouraging activities and actors; (5) provides guidance and resources for action and restrictions and restrictions on activities. The concept of the new institutional existence is supported by three pillars covering regulative, normative, and culturalcognitiv (Scoot; 2008, p.50)

Table 4. Three new institutional presence

\begin{tabular}{|c|c|c|c|}
\hline & $\begin{array}{l}\text { Regulati } \\
f\end{array}$ & $\begin{array}{l}\text { Normati } \\
f\end{array}$ & $\begin{array}{l}\text { Cultural- } \\
\text { Cognitif }\end{array}$ \\
\hline $\begin{array}{l}\text { Basis of } \\
\text { Compliance } \\
\text { Basic } \\
\text { Legitimacy }\end{array}$ & $\begin{array}{l}\text { Appropria } \\
\text { teness }\end{array}$ & $\begin{array}{l}\text { Social } \\
\text { Obligatio } \\
\text { ns }\end{array}$ & $\begin{array}{l}\text { Accepted } \\
\text { on the } \\
\text { basis of } \\
\text { Common } \\
\text { Understand }\end{array}$ \\
\hline Basic Rules & $\begin{array}{l}\text { Regulativ } \\
\text { e Rules }\end{array}$ & $\begin{array}{l}\text { Binding } \\
\text { hope }\end{array}$ & $\begin{array}{l}\text { Constructiv } \\
\text { e Scheme }\end{array}$ \\
\hline Mechanism & Coercion & Normativ & Imitation \\
\hline Logic & Role & Suit & \\
\hline Indicator & $\begin{array}{l}\text { Rules } \\
\text { Law } \\
\text { Sanctions }\end{array}$ & $\begin{array}{l}\text { Endorse } \\
\text { ment } \\
\text { Accredita } \\
\text { tion }\end{array}$ & $\begin{array}{l}\text { General } \\
\text { Beliefs, } \\
\text { Shared } \\
\text { Logic } \\
\text { Actions } \\
\end{array}$ \\
\hline Impact & $\begin{array}{l}\text { Fear and } \\
\text { guilt / sin }\end{array}$ & $\begin{array}{l}\text { Shame / } \\
\text { Honor }\end{array}$ & Confusion \\
\hline $\begin{array}{l}\text { Basic } \\
\text { Legitimacy }\end{array}$ & $\begin{array}{l}\text { Legal } \\
\text { Sanctions }\end{array}$ & $\begin{array}{l}\text { Morally } \\
\text { regulated }\end{array}$ & $\begin{array}{l}\text { Understood } \\
\text { / } \\
\text { understood } \\
\text { Recognized } \\
\text { Culturally } \\
\text { supported }\end{array}$ \\
\hline
\end{tabular}

Source: Reprocessed from Scoot $(2008, \mathrm{~h}, 51)$

\section{RESEARCH METHODS}

The research approach used is qualitative, because this approach is considered more relevant to explore more deeply about the development of local institutions in food security. So this study was conducted on local conditions, and natural time at a local institute (farmer group "Mawar") that manages the integrated livestock integration system in Lubuk Bayas Village.

Informant selection technique in this research use purposive sampling and snowball sampling. The research informants were chosen based on purposive sampling, namely

1. (BP2KP) District of Serdang Bedagai.

2. (PPK) Departement of Agricultural District Serdang Bedagai.

3. Local Government Lubuk Bayas Village.

4. Community leaders who know and actively participate in the management livestock integration system that has been going on from 2002.

5. Management of Farmer Group "Mawar" such as Chairman, Secretary, Treasurer.

For informants selected by using snowball sampling are:

1. Members of the Mawar Farmer Group who know a lot about the manages the integrated livestock integration system program in Lubuk Bayas Village.

2. Community leaders who are also active members of the Mawar Farmer Group.

3. The Farmer Group "Subur", which is an institutional development of the "Mawar" Farmer Group

Data collection techniques conducted in this study are as follows:

1. Study the literature and documentation of various journals, books, research results and other media related to the research topic, but also documentation study to obtain secondary data.

2. In-depth interviews of research informants selected through purposive sampling and Snowball sampling.

3. Group Interview.

4. Field observation.

\section{RESEARCH RESULTS AND DISCUSSION}

Livestock Management System program management activities have become a trigger and 
become an encouragement for the surrounding community and other farmer groups in Lubuk Bayas Village and even farmer groups outside Lubuk Bayas Village to participate in the SIPT program, because sanother farmers out Lubuk Bayas Villages interested in the success of "Mawar" Farmer Group in managing livestock management system program in Lubuk Bayas Village.

The Livestock Management System Program is done by the local institution of Mawar Farmer Group in Lubuk Bayas Village using local institution which has succeeded in providing manure for organic farming and success in running cow breeding so that the availability of cows and ownership of cattle well.

Livestock Management System is able to improve farmers' welfare through increasing Farmers Exchange Rate in "Mawar" farmer group. Increasing Farmers Exchange Rate Because farmers no longer buy fertilizer for their organic farming, because they have been able to produce their own fertilizer so that the cost for agriculture is reduced, and since it has been turned to organic farming farmers do not need chemical pesticide commonly used for spraying rice plants, it also helps reduce farmers' production costs. While for the cow treatment does not incur additional costs because the food obtained from straw and grass are widely available around the settlement.

The success of managing cattle has been enjoyed by group members by getting calves from cow guliran, thus increasing the capital of farmers because the cow will be sold or bred again. Therefore the Farmer's Exchange Rate has increased because the cost for rice production has decreased by running the SIPT program so that the welfare of farmers can increase.

The management of local institutionalbased Livestock Managenet System program requires 3 pillars which in the new institutional theory consist of regulative pillars, normative pillars and cultural pillars of cognitive. These three pillars are the foundation of the success of the local farmer group "Mawar" in managing Livestock Management System, in addition there are several strengthening factors from the local institutional existence of the "Mawar" farmer group that has survived until now. Based on the Colemans' Rational Choice Theory theory of existing institutional as regulative institutions and the advantages gained from institutional existence, it becomes a reinforcing factor of local institutional existence. The same is true of Suradisastra as long as local institutions can provide services to the community, so long as that local institution can survive.

Table. .5. Three new Institutional Pillars in the management of local institutionalbased SIPT programs by the Mawar Farmer Group.

\begin{tabular}{|c|c|}
\hline \multicolumn{2}{|c|}{$\begin{array}{l}\text { Livestock Management System based on Local } \\
\text { Institution of Mawar Farmer Group }\end{array}$} \\
\hline Regulative Pilar & The Farmers Group "Rose" do: \\
\hline $\begin{array}{l}\text { Institutional } \\
\text { Management: } \\
\text { a. } \quad \text { Board rules }\end{array}$ & $\begin{array}{l}\text { The board consists of } \\
\text { Chairman, Secretary, } \\
\text { Treasurer. } \\
\text { - A clear division of labor } \\
\text { between the board and }\end{array}$ \\
\hline b. Members Rules & $\begin{array}{l}\text { Rules for added members other than } \\
\text { having rice fields in Lubuk Bayas } \\
\text { Village, prospective members must } \\
\text { be known to be active and accepted } \\
\text { by the majority of other group } \\
\text { members. }\end{array}$ \\
\hline $\begin{array}{ll}\text { 2. } & \text { Financial } \\
& \text { Management } \\
\end{array}$ & $\begin{array}{l}\text { Group cash from non-regular dues } \\
\text { to sell cattle, at least } 2.5 \% \text { of sales. }\end{array}$ \\
\hline $\begin{array}{ll}\text { 3. } & \text { Membership } \\
& \text { Management }\end{array}$ & $\begin{array}{ll}\text { - } & \text { Development of new } \\
& \text { farmer group members } \\
\text { - } & \text { Giving the right (calf) on } \\
\text { - } & \text { time } \\
& \text { Principles of Democracy } \\
\end{array}$ \\
\hline $\begin{array}{ll}\text { 4. } & \text { Sanctions/Pun } \\
\text { ishmnt } \\
\text { Management }\end{array}$ & $\begin{array}{l}\text { Verbal warning } 3 \text { times, then } \\
\text { dismissal. And the assets owned are } \\
\text { withdrawn to the group }\end{array}$ \\
\hline Normative Pilar & $\begin{array}{l}\text { The Farmers of Mawar are done as } \\
\text { follows: }\end{array}$ \\
\hline $\begin{array}{ll}\text { 1. Performance } \\
\text { Evaluation }\end{array}$ & $\begin{array}{l}\text { Deliberation at the village hall once } \\
\text { every } 3 \text { months to evaluate the } \\
\text { performance of the board, and } \\
\text { members. The development of } \\
\text { managing programs, problems } \\
\text { faced, etc. }\end{array}$ \\
\hline $\begin{array}{ll}\text { 2. } & \text { Social } \\
& \text { Responsbility }\end{array}$ & $\begin{array}{l}\text { Empathy to the affected members, } \\
\text { providing material and non-material } \\
\text { assistance. These actions are at the } \\
\text { initiative of the members }\end{array}$ \\
\hline $\begin{array}{l}\text { Cultural-Cognitif } \\
\text { Pilar }\end{array}$ & $\begin{array}{l}\text { The Farmers of Mawar are done as } \\
\text { follows: }\end{array}$ \\
\hline $\begin{array}{l}\text { 1. Local values } \\
\text { of society }\end{array}$ & $\begin{array}{l}\text { - The use of season } \\
\text { calendars to start planting } \\
\text { time } \\
\text { Local understanding of } \\
\text { PokTan different from } \\
\text { agricultural extension. } \\
\text { (PokTan prefers cows to } \\
\text { be fed fresh grasses rather } \\
\text { than concentrates, and } \\
\text { PokTans prefer cage } \\
\text { cleansing every day } \\
\text { compared to once a week, } \\
\text { because it deals with } \\
\text { aesthetics and cow health. }\end{array}$ \\
\hline
\end{tabular}




\begin{tabular}{|c|c|}
\hline & $\begin{array}{lr}\text { - } & \text { Use of a new interpreter } \\
\text { between } & \text { local } \\
\text { understanding } & \text { and } \\
\text { understanding using new } \\
\text { technology. }\end{array}$ \\
\hline $\begin{array}{ll}\text { 2. } & \text { Culture } \\
& \text { Society }\end{array}$ & $\begin{array}{l}\text { - } \begin{array}{l}\text { Unbalanced tribal } \\
\text { composition } \\
\text { dominance) } \\
\text { - Javanese }\end{array} \\
\text { Misunderstanding of work } \\
\text { and tribal factors are the } \\
\text { cause }\end{array}$ \\
\hline
\end{tabular}

Source: The results of research in if the researcher back

The above table is the conclusion of field findings obtained in the researcher, after grouped the field findings are in accordance with new institutional theory consisting of regulative pillars, normative pillars and cultural-cognitive pillars. In Livestovk Management System program the "Mawar" Farmer Group undertook a series of activities that corresponded to the new institutional theory.

Scoot $(2008$, p.50) argues that the new institutional presence emphasizes service to (1) control community capacity and limit behavior; (2) provides restrictions with legal, moral and cultural boundaries; (3) departing from the lawful from unlawful activity; (4) supporting and encouraging activities and actors; (5) provides guidance and resources for action and restrictions and restrictions on activities. The concept of the new institutional existence above should be supported by three pillars covering regulative pillars, normative pillars and cultural pillars of cognition.

Management of the Livestock Integration System program Based on the local institutional arrangements conducted by the Mawar Farmer Group in Lubuk Bayas Village, the whole has met the regulative pillars, normative pillars and cultural-cognitive pillars as the three main pillars in the new institutional theory. Thus it can be concluded that the three pillars in the new institutional theory has been met by the Mawar Farmer Group Management of the Livestock Integration System program in Lubuk Bayas Village.

Factors reinforcing the local institutional existence of Mawar Farmer Group as follows:

1. Economic Factors

The advantages of this economic factor in the members of the Mawar Farmer Group, because they no longer spend the cost to buy chemical fertilizers and pesticides for rice crops. Because after joining the Mawar
Group the group members use organic fertilizer as a result of management liveristock system and also entitled to get calf (calves) from breeding cows through the process of "guliran" and profit from one adult cow to reach 6-7 million rupiah (depending on condition of cattle).

2. Social/Culture Factors

With the frequent members of the Mawar Farmer Group gathered together to create a close sense of kinship, from here emerges the institutional social responsibility that is ready to assist members of the group who experienced the disaster by providing material and non-material assistance, it can be concluded that social/cultural factors make the local institutional Farmer Group "Mawar" can survive to livestock manage system in Lubuk Bayas Village until now.

3. Knowladge Factors.

The increasing knowledge of the members of the "Mawar" Farmer Group in organic farming and cattle breeding is also a factor of local institutional survival of Mawar Farmer Group in Lubuk Bayas Village in Management of the Livestock Integration System.

Knowledge in the field of organic farming and cow development through artificial insemination marriage in member of Mawar Farmer Group through agricultural extension BP2KP District of Serdang Bedagai and also NGO BITRA with "Sekolah Lapang" method (SP).

With the increased knowledge of the members of the "Mawar" Farmer Group it becomes additional capital for group members to develop their ability to set up new farmer groups and also get agricultural capital investment. The agricultural production of NaTaMa also can be a member of farmer groups from field extension workers and also organic agricultural NGOs that help farmer groups produce their own organic fertilizer.

Based on the results of this study can be concluded that the factor of increasing knowledge of farmers, became one of the factors of local institutional survival of Mawar Farmer Group in system of rice cattle integration at Lubuk Bayas Village.

4. Achievements achieved by Mawar Farmer Group

Achievements achieved by the Mawar Farmer Group in system of rice cattle integration led to the pride of group members being part of the 
Mawar Farmer Group. Such pride makes the institution of Mawar Farmer Group still favored and respected by the people in Lubuk Bayas Village. especially by members and administrators of the Mawar Farmer Group. Such pride enlarges the spirit of members and administrators of the Mawar Farmer Group to continue to manage system of rice cattle integration and organic farming in Lubuk Bayas Village. Assistance capital business development of organic farming from the government.

5. Business Capital Assistance

Lubuk Bayas Village and Mawar Farmer Group get assistance from the Central Government for the development of organic farming business, the assistance is in form of coaching money used for the development of organic agriculture by forming "Subur" Farmer Group which members are part of "Mawar" Farmer Group. Other assistance is also given by the Provincial Government of Sumatra Utara and Serdang Bedagai District in the form of agricultural goods both seeds, agricultural tools and business capital.

Based on the result of the research, it can be concluded that the emergence of new farmer groups from the development of Mawar Farmer Group due to the existence of local institutions combined with the environment around them through three important mechanisms that are coercive, the process to mimetic and the norms in the environment (normative) in which the institutional impact of the dissemination of three mechanisms in the field of organization so that the emergence of new farmer groups, as well as the modeling of SIPT program, conducted by other communities.

There are 5 factors that influence the survival of local institution of Mawar Farmer Group in Lubuk Bayas Village in managing the Livestock Integration System program that is: (1). Economic factors, (2). Social / Cultural Factors, (3). Factors of increasing agricultural knowledge, (4). Achievement factors achieved by Mawar Farmer Group, (5) Business capital assistance factor. These factors are derived from group members and institutional groups of Mawar Farmers, each of which benefits from the local institutional presence of the Mawar Farmer Group. Thus it can be concluded that with the continued advantage of group members and the institutional advantage of the local institutional presence of the Mawar
Farmer Group. Then the local institutional presence of Mawar Farmer Group will survive.

\section{CONCLUSION}

Long before the Management of the Livestock Integration System program entered Lubuk Bayas Village, the Mawar Farm Group had existed and consisted of parents or ancestors who were members of the Mawar Tani Group. Togetherness is an issue that formed the Mawar Farmer Group, precisely in 1974 "Mawar" Farmer Group was established as a form of local institutional acculturation.

This togetherness was formed due to pest attack on farmer rice planthopper, and at that time all the rice fields attacked by planthopper pests that resulted in crop failure in Lubuk Bayas Village. As a result of the pest attack of planthopper make the farmers together work, hand in hand to eradicate pests aphis, and do agricultural activities. This togetherness continues to form the Mawar Farmer Group that still survive until now. For the activities of Management of the Livestock Integration System program in Lubuk Bayas Village developed from the invitation or call from the Village Government And community leaders and the Mawar Farmer Group to the community around Lubuk Bayas Village to participate as members of the Mawar Farmer Group jointly manage the Management of the Livestock Integration System program program.

A. Management of the Livestock Integration System conducted by "Mawar" Farmer Group through three forms:

1. Regulative Pillars. This pillar focuses on institutional management consisting of management structure (Chairman, Secretary, Treasurer). As well as the rules of the management of the Mawar Farmer Group, the membership rules of the Mawar Farmer Group. The financial management of Mawar Farmer Group uses the group cash money from the voluntary donation of the members and at least $2.5 \%$ contribution. Management of the organization with the principles of democracy and wisdom by developing the ability of members to new things. Members' obligations to be fulfilled in the Management of the Livestock 
Integration System and member rights are timely. Management of sanctions/penalties by giving 3 reprimands and dismissal if the member does not change his behavior.

2. Normative Pillar. This pillar focuses on evaluating the performance of the board and members of the Mawar Farmer Group. And management of local institutional social responsibility as a form of empathy towards the members of the group who get the disaster.

3. Cultural-Cognitive Pillar. This pillar is the driving and strengthening of local community values in the management of SIPT, because the Mawar Farmer Group juxtapose the understanding of local values in the care and breeding of cows and organic farming with modern understanding/technology from Badan Penyuluh Pertanian dan Ketahanan Pangan (BP2KP) District of Serdang Bedagai.

The culture of society that becomes resistance but can be addressed wisely by the Mawar Farmer Group by firing members who are lazy to work and replace them with new members who are known and industrious work.

Thus the three pillars (regulative pillars, normative pillars, and cultural-cognitive pillars) contained in the new institutional theory are used by the Mawar Farmer Group in Lubuk Bayas Village in the management of the Livestock Rice Integration System. It is this that led to the success of the local institution of Mawar Farmer Group in the national champions of the villages managed by Management of the Livestock Integration System and the sustainability programe from 2002 up to now is still running.

B. Strengthening Factors of Local Institutional Entity of Mawar Farmer Group in Lubuk Bayas Village Perbaungan Sub-district of Serdang Bedagai Regency

The existence of local institutions that have become part of the community system in Lubuk Bayas Village especially for the Mawar Farmer Group has great benefits for members of the Mawar Farmer Group, the persistence of local institutional existence of Mawar Farmer Group consists of factors as follows:

1. Economic factors
Being a member of the Mawar Farmer Group has the advantage and opportunity to own a cow and help the family economy. This is because farmers no longer buy fertilizer for agriculture because it uses organic fertilizer from SIPT processing

2. Socio-cultural factors

Socially speaking members of the group benefit because they can more harmonious relationships among group members, gathering together in group cages and doing night watch activities to make the members' relationships more harmonious and members are generally happy to do the activity. Villagers also feel safe from the thief's disruption as it is helped by night watch routine performed every night by members of farmer groups.

3. Factors of agricultural knowledge

Members and managers of the Mawar Farmer Group gain new knowledge in agriculture that can be used in organic farming obtained from agricultural extension BP2KP and the Animal Husbandry Office of Serdang Bedagai Regency, new knowledge in agriculture is utilized to produce organic farming and organic fertilizer processed by farmers themselves.

4. A sense of pride because of achievements A sense of pride as a member of the "Mawar" Farmer Group who successfully achieved the achievements of national champions and other champions.

5. Got grant of agricultural business capital Institutional development with government-assisted assistance for organic agriculture.

\section{REFERENCE LIST}

Alston, Margaret and Bowles, Wendy. (2008). Research For Social Worker An Introduction to Methodes. Sidney: Allen and Unwin.

Amang, Beddu dan M. Husein Sawit, (2011). Kebijakan Beras dan Pangan Nasional Pelajaran dari Orde Baru dan Orde Reformasi. IPB : Pers Bogor.

Dewan Ketahanan Pangan. (2006). Kebijakan Umum Ketahanan Pangan 2006-2009. Departemen Pertanian, Jakarta. 
Dewan Ketahanan Pangan, (2011). Kebijakan Umum Ketahanan Pangan 2010-2014. Jakarta: Dewan Ketahanan Pangan.

Hayanto, B. (2003). Sistem Integrasi Padi Ternak (SIPT). Badan Penelitian dan Pengembangan Pertanian, Depetemen Pertanian.

Krueger, Richard A. (2008). Focus Group: Apractical Guide for Applied Research. USA. Sage Publication.

Meleong, Lexy J. (2010). Metode Penelitian Kuantitatif (Edisi Revisi). Bandung: PT Remaja Rosdakarya.

Mulyana, 2003. Metodologi Penelitian Kualitatif, Bandung: PT Remaja Rosdaka

Neuman, W Lawrence. (2006). Social Research Methode: Qualitative and Quantitative Approach (Sixth Editio). Needham Heights. MA: Allyn \& Bacon.

Sastraatmadja, Entang. 2006. Untukmu Dewan Ketahanan Pangan. Bandung : Masyarakat geografi Indonesia.

Scoot, Richard. (1995). Institution and Organization Foundation for Organizational Science. USA. Sage Publication ( $6^{\text {th }}$ ed). USA: Thomson Brooks/Cole

Scoot, Richard. (2008). Institution And Organization: Idea and Interest. USA: Sage Publication.

Sugiyono. (2009). Metode Penelitian Kuantitatif, Kualitatif dan R\&D. Bandung: CV. Alfabeta.

Syarief, dkk. 1999. Pembangunan Gizi dan Pangan Dari Perspektif Kemandirian Lokal. Bogor : Perhimpunan Peminat Gizi dan Pangan Indonesia dan Center For Regional Resource Development \& Community Empowenment.

Wibowo, Agung Pramono Priyo. (2011). Pengembangan Kelembagaan Lokal. Jakarta: Management Studio and Clini

\section{Articles, Magazines and Journals}

Khairiah, Wasito. (2007). Dampak sistem integrasi padi dan ternak sapi dalam rangka pengembangan ternak sapi di Kabupaten Serdang Bedagai, Sumatera Utara. Pusat Analisis Sosial Ekonomi Dan Kebijakan Pertanian Badan Litbang Departemen Pertanian Bogor.

Maleha dan Adi Sutanto, (2006). Kajian Konsep Ketahanan Pangan. Jurnal Protein Vol.13. No.2 Tahun 2006.

Sembiring, T.,Helrni, H.Sembiring, C.Imam, B.Syahrial. (2002).Pengelolaaan Tanaman Terpadu dan Sumberdaya Terpadu PadiSawah Irigasi di DesaLubukBayas, Kecamatan Perbangan,KabDeliSerdang,Sumatera Utara. Laporan Hasil Pengkajian Kerjasama BPTPSumatera Utara dengan Dinas Pertanian Tanaman Pangandan Hortikultura. KabDeli Serdang.

\section{Internet Source:}

Muchjidin, Rachmat. (2013).“Nilai Tukar Petani: Konsep, Pengukuran dan Relevan Sebagai Indikator Kesejahteraan Petani, Forum Penelitian Agro Ekonomi Volum 31 No.2 Desember 2013 halaman 111$122 \quad$ (27 Januari 2015. http://pse.litbang.pertanian.go.id/ind/ pdffiles/FAE31-2_b.pdf, )

Wafa, Indra. (2013). "Gambaran Umum Pangan Dunia. $\quad$ (08 September 2014. http://www.paskomnas.com/id/berita /gambaran-umum-pangan-dunia.php) 